\title{
Notice of Correction
}

(D) CrossMark

Re: Bockeria LA, Svanidze O, Kim A, Shatalov K, Makarenko V, Cox M, Carrel T. Total cavopulmonary connection with a new bioabsorbable vascular graft: First clinical experience. J Thorac Cardiovasc Surg. 2017;153:1542-50.

In the above-mentioned article, the legends to Figures 2 to 4 were correct but printed with the incorrect figures. The corrected figures are reprinted below.

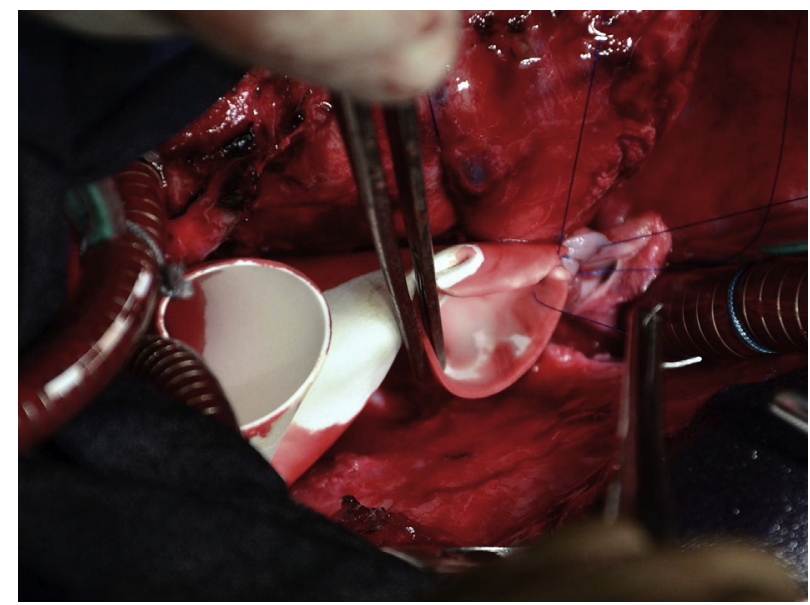

FIGURE 2. Intraoperative site: implantation of the novel vascular graft between the inferior vena cava and the pulmonary artery.

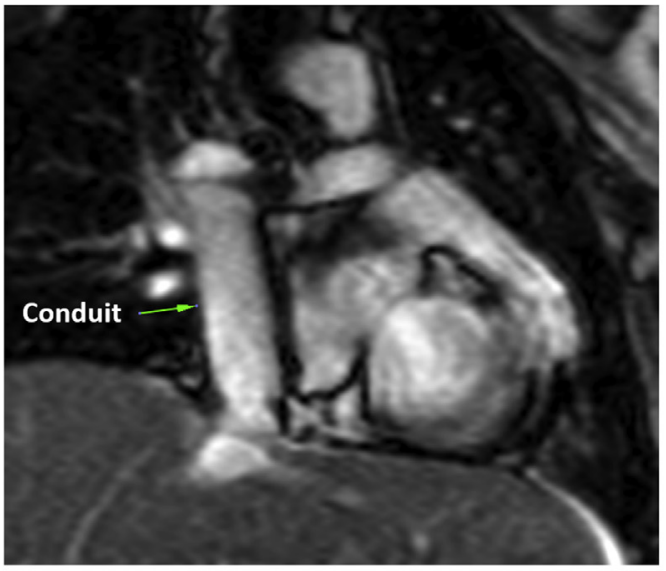

Frontal

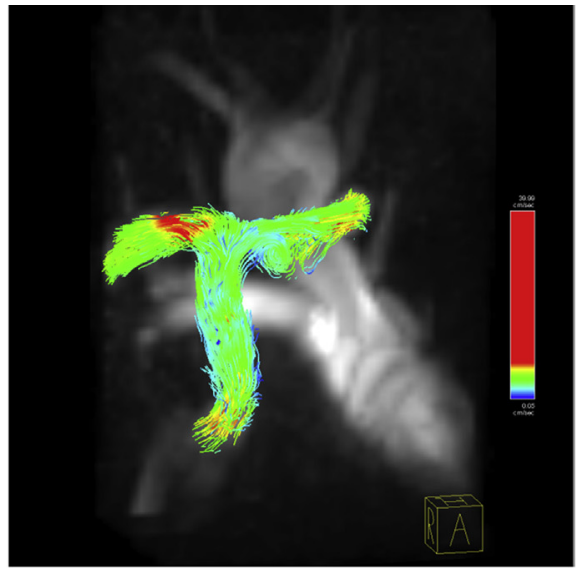

4D-Flow

FIGURE 3. Magnetic resonance imaging of the vascular graft at 6 months' follow-up in Patient 1, showing frontal view of graft and 4-dimensional imaging view that demonstrate the patency of the conduit. 

E: endothelium
GC: multinucleated giant cells
M: macrophages
L: leukocytes
BV: blood vessels
C: collagen fiber
GC: multinucleated giant cells
Elastin fibers:
Conduit material:

\section{Cell infiltration Tissue formation Graft replacement Graft removal}
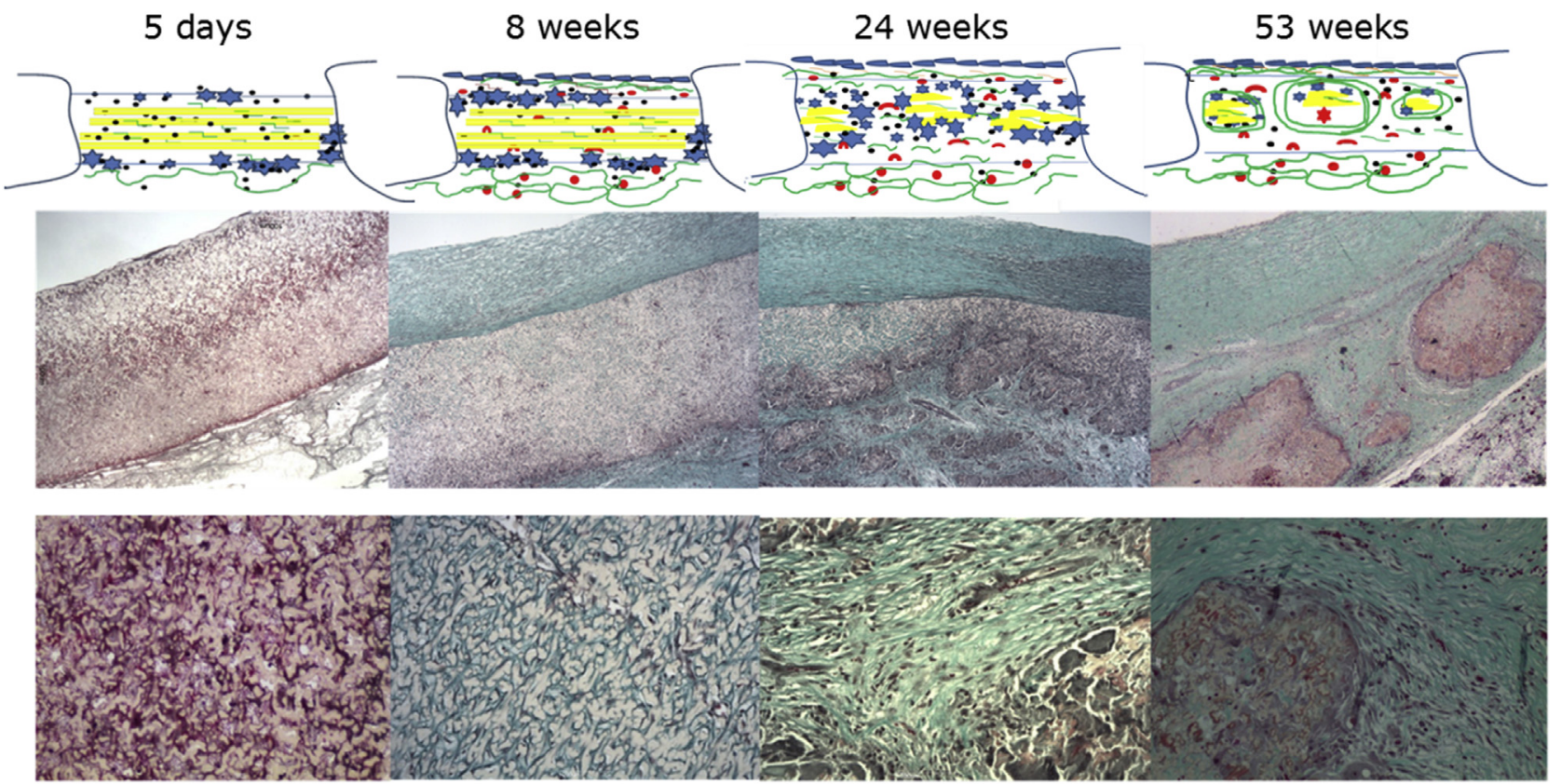

FIGURE 4. Process of bioabsorption observed with the Xeltis new vascular graft: cell infiltration, tissue formation, graft replacement, and graft removal (up to 53 weeks). Data from preliminary experiments. Adapted from Schoen and colleagues, ${ }^{22}$ with permission. 